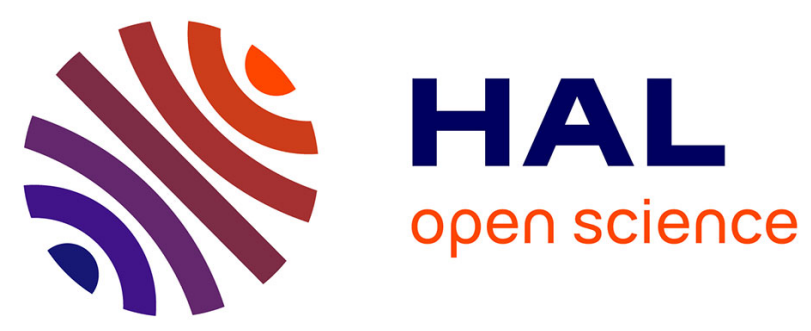

\title{
Heritabilities and GxE interactions for growth in the European sea bass (Dicentrarchus labrax L.)
}

\author{
Mathilde Dupont-Nivet, Marc Vandeputte, Alain Vergnet, Olivier Merdy,
} Pierrick Haffray, Hervé Chavanne, Béatrice Chatain

\section{To cite this version:}

Mathilde Dupont-Nivet, Marc Vandeputte, Alain Vergnet, Olivier Merdy, Pierrick Haffray, et al.. Heritabilities and GxE interactions for growth in the European sea bass (Dicentrarchus labrax L.). 9. International Symposium on Genetics in Aquaculture, Jun 2006, Montpellier, France. pp.S253-S254, 10.1016/j.aquaculture.2007.07.053 . hal-02753042

\section{HAL Id: hal-02753042 \\ https://hal.inrae.fr/hal-02753042}

Submitted on 3 Jun 2020

HAL is a multi-disciplinary open access archive for the deposit and dissemination of scientific research documents, whether they are published or not. The documents may come from teaching and research institutions in France or abroad, or from public or private research centers.
L'archive ouverte pluridisciplinaire HAL, est destinée au dépôt et à la diffusion de documents scientifiques de niveau recherche, publiés ou non, émanant des établissements d'enseignement et de recherche français ou étrangers, des laboratoires publics ou privés. 
Comparison of pressure or thermal treatments on triploid yields and malformations up to swim up stage in rainbow trout (Oncorhynchus mykiss)

\author{
P. Haffray ${ }^{\text {a }}$, J. Aubin ${ }^{\text {b }}$, V. Houis ${ }^{\text {c }}$, L. Labbe ${ }^{\text {c }}$, \\ B. Jalabert ${ }^{d}$ \\ ${ }^{a}$ SYSAAF, Station SCRIBE/INRA, Campus de \\ Beaulieu, 35042 Rennes, France \\ ${ }^{\mathrm{b}}$ INRA, 65, rue de St Brieuc, 35042 Rennes, France \\ c PEIMA, Barrage du Drennec, 29450 Sizun, France \\ d INRA, Station SCRIBE, Campus de Beaulieu, 35042 \\ Rennes, France
}

Effects of pressure or thermal treatment performed at fertilization to induce triploidy were assessed by monitoring survival rates at eyed, hatching and swim-up stages, and morphological anomalies in surviving fry. Pressure treatment (at 700 bars), thermal treatment (at $26.6^{\circ} \mathrm{C}$ ) and control fertilization were performed on the same 14 spawns of individual females of rainbow trout (INRA UR544 Génétique des Poissons, F-78350 Jouy en Josas, France). Fry ploidy was assessed by flow cytometry at yolk sac stage on 80 larvae per treatment. Fry triploid rates were not statistically different between pressure and thermal treatments $(97.5 \% \pm 3.5$ and $92.9 \% \pm 5.6)$. However, survival was significantly better after pressure rather than thermal treatment, either at eyed stage $(89.5 \%$ vs. $68.0 \%)$ or at hatching $(96.8 \%$ vs. $92.3 \%)$, and was not different from diploid control. Nine different types of morphological anomalies were noticed at swim up stage. The global rate of anomalies was not different between pressure treatment and diploid control (2.8\% vs. $1.9 \%)$, but was significantly higher in fry from thermal treatment (11.7\%). The pressure treatment induced a final yield of fry similar to diploid control, but significantly higher than the thermal treatment $(81.7 \%$ vs. $49.6 \%)$. Data analysis of morphological anomalies types and rates, recorded at swim up stage, displayed an interaction between individual spawns and triploidisation treatments. Finally, no difference in performances and morphological anomalies rates could be observed in this experiment, at hatchery stages, between triploid fry from pressure treatment and control diploids.

doi:10.1016/j.aquaculture.2007.07.079

\section{Heritabilities and $G \times E$ interactions for quality traits in the European sea bass (Dicentrarchus labrax L.)}

P. Haffray ${ }^{a}$, C. Pincent ${ }^{a}$, M. Dupont-Nivet ${ }^{\text {a,b }}$, M. Vandeputte ${ }^{\text {b,c }}$, O. Merdy ${ }^{b}, H$. Chavanne $^{\text {d }}$, B. Chatain ${ }^{\mathrm{c}}$
${ }^{\text {a }}$ SYSAAF Section aquacole, Station SCRIBE, Campus de Beaulieu, F-35042 Rennes, France

b INRA UR544 Génétique des Poissons, F-78350 Jouy en Josas, France

${ }^{\mathrm{c}}$ Ifremer, Chemin de Maguelone, F-34250 Palavas-lesFlots, France

d Panittica Pugliese, I-72010 Torre Canne di FasanoBR, Italy

253 families of the European sea bass Dicentrarchus labrax were pooled in the tank and reared communally from hatching, dispatched in 4 different farming systems (semi-intensive ponds, cages, race ways and closed recirculated system), slaughtered (338 to $487 \mathrm{~g}$ ) and identified by genotyping of microsatellites. Indirect estimation of muscle fat content by microwaves (Torry Fish Fat Meter) was linearly related with the real content estimated by NMR $\left(R^{2}=0.70, n=200\right)$. Heritabilities of Fat Meter values were high in all sites and for all the positions $(n=3)$ of the meter (from $0.43 \pm 0.05$ to $0.77 \pm$ 0.07). Genetic correlations between sites (used to estimate $G^{*} E$ interactions) varied from $0.70 \pm 0.07$ to $0.96 \pm 0.02$. The genetic correlation between fat muscle fat and growth was intermediate $(0.46 \pm 0.09$ to $0.65 \pm$ 0.06). Selection for growth will induce the production of fatter fish when fish will be slaughtered at the same age, but this increase is mainly due to the positive phenotypic correlation between weight and fat content. However, if fish will be slaughtered at the same weight, different correlated responses are observed from the production of leaner to fatter fish depending on farms. Heritability of carcass yield was medium to high (0.58 to 0.74$)$ and this trait was highly correlated with the fat deposited around the digestive tract $(-0.98 \pm 0.01)$ but independent with the fat deposed at the top of the belly cavity $(-0.01 \pm 0.10)$. It is concluded that improvement of quality traits in sea bass can be initiated and that rapid progress could be achieved in most traits recorded in this experiment.

doi:10.1016/j.aquaculture.2007.07.080

Identifying regions of the genome responsible for early maturation and associated traits in rainbow trout (Oncorhynchus mykiss)

L. Haidle, J. Janssen, K. Gharbi, R.G. Danzmann, M.M. Ferguson

Department of Integrative Biology, University of Guelph, Guelph, Ontario, Canada 